\title{
INDIA AND PAKISTAN: COMMON IDENTITY AND CONFLICT
}

\author{
Samar Hasan \\ Webster University, Geneva
}

The experience of migration offers a particularly interesting context for exploring personal and social identity. When people cross borders, despite their efforts to cope with the new setting, migrants cannot help but remain linked in some way to their country of origin. Often, the search for identity is a problem for migrants. This is why, in migration issues, identity has to be studied in detail since it plays a key role in affecting developments. In the case of India and Pakistan, the issue has been the establishment and reinforcement of a separate and unique identity, and often this has led to distress and further enstrangement between the two nations.

\section{INTRODUCTION}

India and Pakistan came into existence as two separate nation-states in 1947. They have a history of only fifty-seven years of existence as separate countries as compared to about a thousand years of joint existence before the British Raj. Their common identity revolves around aspects of shared history, geography, language, culture, values, and traditions. However, during partition, only one aspect of the identity was considered i.e. the religious identity of the peoples of India.

Over the years, common identity has often been suppressed and buried under the pressure of the conflict of identity between India and Pakistan. One expression of the conflict between India and Pakistan is the issue of Kashmir. This conflict has continued ever since the partition of the Indian sub-continent in August 1947. Kashmir is an open conflict similar to the Israel-Palestine conflict, and has continued over more than half a century. While many people do not realize the gravity of the issue, it is a central issue in Indian-Pakistani relationship, and we need to address this issue. The two countries have to find a solution to the deeper and broader conflict in order to enable them to develop friendly ties with each other.

My paper aims to discuss the various aspects of identity shared by both India and Pakistan and suggests some solutions for the conflict of identity. I will briefly explain the process that led to the creation of Pakistan, and the continuing conflict since then over Kashmir. I will also outline the different levels of identity and how Indians and Pakistanis share a common identity that has, at the same time, some distinctive characteristics. Finally, I would like to suggest what steps India and Pakistan might take to be able to overcome their differences and co-exist peacefully.

\section{BRIEF HISTORICAL BACKGROUND}

There were various social groups and communities living in India, and the country was far from being a homogenous society. Two major groups were Hindus and 
Muslims. For about a thousand years before the advent of the British rule in India, Hindus and Muslims had lived side by side in separate social compartments, accommodating each other's beliefs. ${ }^{1}$

However, the establishment of British rule was accompanied by radical changes in the political and economic structure of the country as well as the intellectual life. In the early nineteenth century, introduction of Western ideas and English education created discontent among Muslims. While Hindus eagerly accepted Western ideas, Muslims rejected English education. The replacement of Persian by English in 1837 severely affected Muslim employment in government sectors, and by the middle of the century, Muslims were well behind the Hindus in progress. They were lagging behind in education and training, were unemployed or in low-income jobs, thus they were also financially less stable. Much of this uneven development of the two communities became responsible for the mutual communal distrust between Hindus and Muslims that finally led to the Partition of India. The Revolt of 1857 relinquished all power in the hands of the British, and the defeat was felt most strongly by the Muslims. The privileges they had enjoyed earlier disappeared, and in the aftermath of the Revolt, the British were also prejudiced against them. ${ }^{2}$

\section{BRITAIN'S DISENGAGEMENT POLICY}

Another factor that led to the separation of the country was Britain's colonial disengagement policy. According to Dr. Sumit Ganguly, Britain's colonial disengagement policy exacerbated the ideological differences between the Congress and the Muslim League. ${ }^{3}$ He says:

"Separatism became a resource that the British regime cultivated and exploited for its own purposes. The more "separate" Muslims came to feel, the more readily could the foreign rulers contend that antipathies between Hindus and Muslims made nationhood for the Indian people impossible."

Initially, the British adopted this policy so that Hindus and Muslims would realize how futile it was for them to try and obtain nationhood. They wanted to demonstrate that the two sides could only live together under British rule. Yet, the differences between the two sides became irreconcilable, and instead of sorting out the mess, the British handed over the control hastily when the Congress and the Muslim League reached a political stalemate beyond British control.

\section{Was the Creation of Pakistan inevitable?}

Many scholars have questioned whether the existence of Pakistan was unavoidable or whether there were other ways of organizing the country without separating the two groups. Was this truly inevitable? It is true to say that the British found this as the easiest way. Yet, at the same time, we must understand that the ideologies of Islam and Hinduism were separate and unique. Jinnah, the founder of Pakistan wrote,

"The Hindus and the Muslims belong to two different philosophies, social customs, literatures. They neither intermarry nor interdine together and indeed,... 
they belong to two different civilizations which are based on conflicting ideas and conceptions..."

However, they had been able to co-exist for a thousand years. The main reason was that they did not feel threatened by each other. They were able to maintain their own individual religious identity as Hindus and Muslims, practice their religion freely and at the same time, they were able to maintain their joint Indian identity. Yet, with the British policy of divide and rule, the differences between them were highlighted to the extent that they became a burden. This gulf was intensified by British colonial policy and created a fear of "Hindu domination" that resulted in the creation of Pakistan, a predominantly Muslim country. ${ }^{5}$ In such circumstances, I believe that there was no other option but to create Pakistan.

To this day, the feeling of separateness exists, and communal violence has continued in India. There are about a hundred deaths every year, and in 1980, there were 400. In 1998-99, 275 people were killed in the state of Gujerat. ${ }^{6}$ In 2002, about 1,000 Muslims were killed in Gujerat, their homes burnt and properties destroyed. ${ }^{7}$ This has given reason to Pakistan to declare that India makes false claims about being a secular state. In 1992, the Baburi Mosque that was built during the Mughul Empire, was demolished. In retaliation, the Pakistani population destroyed the few mandirs that remained in Pakistan. Communal violence has been less in Pakistan since it is a predominantly Muslim country with only 3\% non-Muslim population.

If we look at the tremendous upheaval that was created in society upon separation in 1947, it is hardly surprising that there were feelings of bitterness and mistrust on both sides. During partition, new boundaries were drawn up without consideration for local interests and loyalties. Villages, clans, families were split up instantaneously. Irrigated land was cut away from the source of water. Both countries faced an explosion of communal violence. Millions left their homes in Punjab while Hindu, Muslim, and Sikh fanatics slaughtered each other mercilessly. Communal riots in East Punjab forced more than six million Muslims from East Punjab to migrate to Pakistan. ${ }^{8}$ Crowded trains would reach Pakistan with not a soul alive. Hundreds of villages were burnt in both countries, and it is estimated that a million people died during partition. Approximately seven million people crossed from India to Pakistan and slightly more migrated the other way. ${ }^{9}$

However, India and Pakistan must remember that this is what happens in wars and armed conflicts. War is not a victory for any one side. The losses are plenty and shared by all parties. To continue living in the past will not help either party. If we say that it became impossible for them to live together, how is it that they are unable to stand each other now that they are separate countries?

\section{KASHMIR}

The issue of Kashmir is also a bone of contention. At the time of independence, there were more than hundred princely states in undivided India. While Pakistan constituted of all the provinces with a Muslim majority, the princely states had their own choice to accede to either side. 
The princely state of Kashmir had a Hindu prince (Raja) who belonged to the Dogra tribe. The Raja decided to accede to India, and did not properly consider the views of the masses, which were predominantly Muslims. Pakistan insisted that all Muslim majority areas should be handed over to the new Muslim state. However, India was intent on demonstrating that all minorities could flourish under a secular government. ${ }^{10}$

Soon after the formation of the two new states, there was a local uprising in Kashmir. The Kashmiris had the support of Pakistan, and they received aid from the Pashtun tribal region of the country. These 1948 border skirmishes had the result that one-third of Kashmir went to Pakistan, while India maintained control over two-third of the region.

A UN resolution was passed in 1948 that insisted on a referendum to be held in Kashmir. Through this referendum, they could either choose self-rule or decide to become a part of either India or Pakistan. India accepted the ruling but so far it has been put off and has not been implemented till now.

\section{Common Identity}

The process of peace is a long process, and it is not possible to establish peace over night. But, it is an achievable goal, and both countries are in a dire need to establish friendly relations with each other. War is a terrible thing, because no one is victorious. All sides suffer losses. Yet, to view each other as enemies is not the solution. France and Germany too have had a history of waging wars against each other. Yet, today the way they have handled the issue is not by eliminating their identity, but by no longer viewing it as a source of enmity. Both French and Germans have a clear identity of their own.

There are several ways of dealing with different identities: accepting the different; changing the different, rejecting the different. The consequences can either be fear or harmony, integration or assimilation. ${ }^{11}$ For India and Pakistan the challenge today is of accepting not rejecting each other, so that they can harmonise relationships among each other.

\section{GENERAL ASPECTS/ISSUES OF IDENTITY}

There are various aspects of identity. Citizenship-nationality is one of them. Language, political values and traditions, culture, history, social conditions, profession, religion, economic conditions, race, ethnicity, friends-enemies are all different aspects of identity. ${ }^{12}$ Indians and Pakistanis share many of these aspects and more. Existing together for centuries, both Hindus and Muslims exchanged many of their traditions, and the Muslims who migrated to Pakistan carried these traditions over to the new country.

Respect for elders is an innate part of the South Asian culture. The family values are very strong and the family system is extremely close-knit. Obedience is a special virtue in the Indian and Pakistani youth, and even today, the tradition of arranged marriage continues. The culture is very similar. Both Indians and Pakistanis often don the same clothes. Muslim weddings across the Middle East are 
usually in white. However, Pakistani brides wear red or other bright colours like Indian brides. Furthermore, while dowry is not a Muslim tradition, Pakistanis incorporated the dowry system from their combined existence with Indians.

\section{OLD ENEMIES, NEW FRIENDS?}

Why is it that even after almost six decades, Indians and Pakistanis view each other in a hostile manner? In Europe also, we have seen the gradual transformation of enemies into friends. India and Pakistan should learn from the example of Europe. After the Second World War, European States realized that, on their own, they were incapable of maintaining peace, and some sort of unification was essential to ensure that peace was maintained. No one was able to predict the future of Europe, yet states shared a common ideal and they had a firm will to avoid a catastrophe similar to World War I and World War II.

While on one hand, this feeling dominated throughout Europe, it was also fairly obvious that deep-rooted feelings of hostility could not simply vanish suddenly. Nor could they be overcome by the restoration of traditional "good neighbourhood" relations. In fact, an authentic reconciliation was absolutely necessary. Western European countries first adopted the formula of cooperation and then, through the creation of European Community, started to take steps towards integration. As a result, the European Union was formed by the reconciliation of countries that had fought against each other just a few years before.

We can observe clearly that the first step in the process in Western Europe was a desire to establish peace. India and Pakistan need to develop this desire so that they will take useful steps in that direction. Using emotive language and blaming the other side is no longer a valid option. Government spending on defense from both sides has strained the economy immensely, and it has to be drastically reduced. While it is true to say that both countries have made progress, they could have achieved present development at a faster rate if they had stopped viewing each other as enemies.

\section{CONCLUSION}

Education is necessary at the base and good leadership is needed at the top. With the recent elections in India, we have seen that Indians did not want a strong Hinduist party any more. Meanwhile, in Pakistan, Mr. Musharraf has been cracking down on the various Islamist groups that foster resentment against India. However, India also needs to cut down on her forces in Kashmir to reduce border tensions. One key question that both sides should address is: what do the Kashmiris want? They should be brought into the decision making process as well, and be present in multilateral bodies to discuss the future of Kashmir. Both countries are nuclear powers and war is just not an option. At the same time, defense spending must be reduced drastically so that government funds can be allocated to more deserving areas, such as economic development, development of infrastructure, education, health, etc. India and Pakistan should aim to increase trade between each other and strengthen their economic relations. 
It is especially important for India to re-establish contact with Pakistan and vice versa. Pakistanis and Indians should be able to travel freely between the two countries. India and Pakistan have lost so much through their continued hostility; culturally, socially and, most importantly, economically.

While ASEAN (Association of South-East Asian Nations) is a regional institution that has helped South-East Asian countries progress with leaps and bounds, SAARC (South Asian Association for Regional Cooperation) has faced disappointments due to hostility between India and Pakistan.

India, Pakistan, and Bangladesh are three very important and populous countries in the region. If they want to succeed and develop, they have to move together. I believe that once they start cooperating at other levels, they will foster closer relations, and they will move closer to a reconciliation of their differences. It has been almost sixty years since independence, and I think it will be a great misfortune for both India and Pakistan if they continue along the same path for the next decade.

\section{REFERENCES}

Akbar, M. J., India: The Siege Within: Challenges to a Nation's Unity, Penguin Books Ltd, Middlesex, England, 1985

Ganguly, Sumit, The Origins of War in South Asia, Westview Press, Inc., U.S.A. 1986

Harrison, Selig S, Paul H. Kreisberg and Dennis Kux, India and Pakistan: The First Fifty Years, Woodrow Wilson Center Press and Cambridge University Press, U.S.A., 1999

Hieronymi, Otto, Notes from his course, "Comparative Politics: Migration and Refugee Movements: the Challenge of Identity and Integration," Webster University Geneva

Jaffrelot, Christophe (ed.), Pakistan: Nationalism without a Nation, Zed Books Ltd. UK, 2002

Mason, Colin, A Short History of Modern Asia, Palgrave, New York, 2000

Ramesh, Randeep, “Two years on, Gujarat's wounds are still raw," The Guardian, http://www.guardian.co.uk/international/story/0,1154420,00.html, Feb 24, 2004

Shehab, Rafi Ullah, Fifty Years of Pakistan, Maqbool Academy, Lahore, 1990

Spear, Percival, A History of India 2, Penguin Books Ltd, Middlesex, England, 1982

Singhal, Damodar P., Pakistan, Prentice-Hall Inc., New Jersey, 1972

Wolpert, Stanley, A New History of India Fourth Edition, Oxford University Press, New York, 1993 


\section{Notes}

$1 \quad$ Singhal, Damodar P., Pakistan, Prentice-Hall Inc., New Jersey, 1972, p. 37

2 Ibid, p. 38-39

3 Ganguly, Sumit, The Origins of War in South Asia, Westview Press, Inc., U.S.A. 1986, p.10

$4 \quad$ Ibid, p. 26

5 Harrison, Selig S, Paul H. Kreisberg and Dennis Kux, India and Pakistan: The First Fifty Years, Woodrow Wilson Center Press and Cambridge University Press, U.S.A., 1999

6 Mason, Colin, A Short History of Modern Asia, Palgrave, New York, 2000, p. 185

7 Ramesh, Randeep, “Two years on, Gujarat's wounds are still raw,” The Guardian, http://www.guardian.co.uk/ international/story/0,1154420,00.html, Feb 24, 2004

8 Shehab, Rafi Ullah, Fifty Years of Pakistan, Maqbool Academy, Lahore, 1990, p. 54

9 Mason, Colin, A Short History of Modern Asia, Palgrave, New York, 2000, p. 179-184

10 Ganguly, Sumit, The Origins of War in South Asia, Westview Press, Inc., U.S.A. 1986

11 Hieronymi, Otto, Notes from his course, "Comparative Politics: Migration and Refugee Movements: the Challenge of Identity and Integration," Webster University Geneva

12 Ibid 